\title{
MHRA

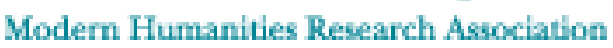

The Laurentian Text (Cod. Laurent. XXIX, 8) of Dante's Letter to a Friend in Florence (Epist. IX), with Emended Text and Translation

Author(s): Paget Toynbee

Source: The Modern Language Review, Vol. 11, No. 1 (Jan., 1916), pp. 61-68

Published by: Modern Humanities Research Association

Stable URL: http://www.jstor.org/stable/3713584

Accessed: 24/06/2014 21:22

Your use of the JSTOR archive indicates your acceptance of the Terms \& Conditions of Use, available at

http://www.jstor.org/page/info/about/policies/terms.jsp

JSTOR is a not-for-profit service that helps scholars, researchers, and students discover, use, and build upon a wide range of content in a trusted digital archive. We use information technology and tools to increase productivity and facilitate new forms of scholarship. For more information about JSTOR, please contact support@jstor.org.

Modern Humanities Research Association is collaborating with JSTOR to digitize, preserve and extend access to The Modern Language Review. 


\title{
THE LAURENTIAN TEXT (COD. LAURENT. XXIX, 8) OF DANTE'S LETTER TO A FRIEND IN FLORENCE (EPIST. IX),
}

\author{
WITH EMENDED TEXT AND TRANSLATION.
}

Dante's letter to a Friend in Florence (Epist. IX in the Oxford Dante) has been preserved in one MS. only, in the Laurentian Library at Florence (xxIx, 8), which contains also Dante's letter to the Italian Cardinals (Epist. VIII), and that to a Pistojan exile, commonly identified with Cino da Pistoja (Epist. Iv), of neither of which is any other MS. known; as well as the letter of Frate Ilario to Uguccione della Faggiuola, and the Latin poetical correspondence between Dante and Giovanni del Virgilio. This MS. belonged to Boccaccio, and the portion containing the three letters of Dante, and the other pieces above mentioned, is in his handwriting; it was executed probably about the year $1348^{1}$.

This letter, which was written by Dante probably in 1315 , to a correspondent who has been conjectured to be his brother-in-law, Teruccio Donati ${ }^{2}$, scornfully rejecting the offer of a return to Florence under certain degrading conditions, was utilised by Boccaccio in his Vita di Dante. In the chapter headed Qualità e Difetti di Dante he writes :

Fu il nostro poeta, oltra alle cose predette, di animo alto e disdegnoso molto; tanto che cercandosi per alcuno suo amico il quale a istanza de' suoi prieghi il faceva, ch' egli potesse ritornare in Firenze (il che egli oltre ad ogni altra cosa sommamente desiderava) nè trovandosi a ciò alcun modo con coloro li quali il governo della republica alloro aveano nelle mani, se non uno, il quale era questo, che egli per' certo spazio stesse in prigione, e dopo quello in alcuna solennità publica fosse misericordievolemente alla nostra principale chiesa offerto, e per conseguente libero e fuori d' ogni condennagione per adrieto fatta di lui; la qual cosa parendogli convenirsi e usarsi in qualunche è depressi e non infami uomini e non in altri, perchè oltra al suo maggiore desiderio, preelesse di stare in esilio, anzi che per cotal

1 See Hauvette, Notes sur des Manuscrits autographes de Boccace à la Bibliothèque Laurentienne, p. 50.

2 See A. della Torre in Bullettino della Societì Dantesca Italiana, N.S. xII, p. 160. 


\section{The Laurentian Text of Dante's Letter to a Friend}

via tornare in casa sua. $O$ isdegno laudevole di magnanimo, quanto virilmente operasti riprimendo l'ardente disio del ritornare per via meno che degna a uomo nel grembo della filosofia notricato! 1

The letter was first printed, in a very imperfect text, at Verona in 1790, by G. J. Dionisi, in the fifth volume (pp. 176-7) of his Serie di Aneddoti, and was reprinted by him at Verona in an emended, but still far from satisfactory, text in his Preparazione istorica e critica alla nuova edizione di Dante Allighieri in 1806 (Vol. I, pp. 71-3). The letter was reproduced, avowedly from Dionisi's original text, but with sundry modifications, by F. Cancellieri in his Osservazioni sopra l' Originalità della Divina Commedia di Dante, published at Rome in 1814 (pp. 59-60); and a few years later by De Romanis in the notes to his edition of Tiraboschi's Vita di Dante (Roma, 1817, pp. 46-7). In 1823 Ugo Foscolo reprinted the MS. text (into which he introduced several patent blunders) in his Essays on Petrarch (pp. 276-7), with an English translation (pp. 203-5). In the same year the letter was reprinted at Florence from Dionisi's Aneddoti, with several variations, in the second edition of Giuseppe Pelli's Memorie per servire alla Vita di Dante (p. 204). In 1827 Witte printed the letter at Padua in his Dantis Alligherii Epistolae quae exstant (Epist. viII, pp. 65-6). Witte's text was reprinted (with certain modifications) at Florence by Fraticelli in 1840, in Dantis Aligherii Epistolae quae exstant (Epist.v, pp. 282-6); and at Leghorn by Torri in 1842, in Epistole di Dante Allighieri edite $e$ inedite (Epist. XIII, pp. 96-8). In 1845 the letter was printed once more from the MS. in Tre Epistole Latine di Dante Allighieri, published at Prato (Epist. III, pp. 23-5) by Luigi Muzzi, whose professedly critical text is, however, vitiated by sundry arbitrary and uncalled for emendations, several of which, as appears from the Italian translation which he printed at the same time, were evidently due to his misunderstanding of the original. In 1857 Fraticelli published at Florence a revised text, with conjectural emendations of his own, in Dantis Aligherii Epistolae (Epist. x, in Opere Minori di Dante, ed. 1893, Vol. III, pp. 500-2), which was reprinted (with a few variations) at Florence in 1882 by Giuliani in Le Opere Latine di Dante Allighieri (Epist. IX,

1 Ed. Macri-Leone, \$ 12 . In the so-called Compendio, which Barbi has proved to be a revised version of the Vita, due to Boccacoio himself (see Bull. Soc. Dant., N.S. xxI, p. 48), the account is much briefer: 'Fu adunque il nostro Poeta, oltre alle cose di sopra dette, d' animo altiero e disdegnoso molto, tanto che cercandosi per alcuno amico come egli potesse in Firenze tornare, nè altro modo trovandosi, se non che egli per alcuno spazio di tempo stato in prigione, fosse misericordievolmente offerto a San Giovanni, fu per lui a cid, ogni fervente disio del ritornare calcato, risposto, che Iddio togliesse via, che alcuno che nel seno della filosofia allevato e cresciuto fosse, divenisse candelotto del suo comune.' (Ed. Rostagno, \& 22.) 
Vol. II, pp. 32-3) ; and at Oxford in 1894 (and again in 1897 and 1904) by $\mathrm{Dr}$ Moore in the Oxford Dante (Epist. Ix, pp. 413-14). A diplomatic transcript of the MS. text was published in the Bullettino della Società Dantesca Italiana for May-June 1905 (N.S. XII, pp. 122-3) by Arnaldo della Torre, several of whose proposed emendations were introduced into the latest reprint of the letter, namely that of Passerini', in his edition of Le Opere Minori di Dante (Firenze, 1910, Epist. Ix, pp. 96-100).

At the end of last year (1914), in (belated) commemoration of the sixth centenary of the birth of Boccaccio (1313), a facsimile of the whole of Cod. Laurent. xxIx. 8 was published at Florences. By means of this facsimile I have been able to make a fresh transcript of the MS. text of Epist. IX, which is subjoined below, together with an apparatus criticus, in which are registered variant readings from the printed editions enumerated above. The various editions in question are represented in the apparatus criticus as follows:

$\mathrm{D}^{1} .=$ Dionisi $(1790) ; \mathrm{D}^{2} .=$ Dionisi $(1806) ;$ C. $=$ Cancellieri (1814); $\mathrm{R} .=$ De Romanis $(1817) ; F_{0}=$ Foscolo (1823); Pe. = Pelli (1823); $\mathrm{W} .=$ Witte $(1827) ; \mathrm{F}^{1} .=$ Fraticelli $(1840) ; \mathrm{T} .=$ Torri $(1842) ; \mathrm{M} .=$ Muzzi (1845); F ${ }^{2}=$ Fraticelli (1857); G. = Giuliani (1882); O.= Oxford Dante (1904); To. =A. della Torre (1905); P.= Passerini (1910); $D^{1}$.-P. $=D^{1} \cdot D^{2}$.C.R.Fo.Pe.W.F'.T.M.F ${ }^{2}$.G.O.P., it being understood that any edition mentioned independently in the same note is excluded.

Appended is a trial list of proposed emendations in the 'standard' text as printed in the Oxford Dante, together with a transcript of the text as emended, and an English translation of the same.

As in the case of previous transcripts printed in this Review, the contractions of the MS. have been expanded, the expansions being printed in italics. The punctuation of the MS., such as it is, has been preserved. For convenience of reference, as before, the text of the letter has been broken up into paragraphs, numbered [in square brackets] to correspond with the numbering of the sections in the Oxford Dante. In the MS. the letter, which is without title, and follows immediately after that to the Pistojan exile (Epist. Iv), occupies the last twelve lines (ll. 43-54, numbered in round brackets in the transcript) of fol. $63^{\text {ro }}$.

\footnotetext{
1 The principal divergencies from the MS. of Fraticelli's text were registered by 0. Zenatti in Dante e Firenze (p. 532); as were those of Giuliani's text by G. Mazzoni in the Bullettino della Società Dantesca Italiana for March-April, 1898 (N.S. v, p. 98, n. 1).

2 This reprint is disfigured by several careless misprints, which will be found registered in the apparatus criticus below.

3 Lo Zibaldone Boccaccesco Mediceo Laurenziano (Plut. xxIx, 8). In Firenze, presso Leo S. Olschki, Mcmxiv.

4 For example, note 2 on p. 64 indicates that M. follows the MS. and reads et, while all the other editions read $e x$.
} 


\section{The Laurentian Text of Dante's Letter to a Friend}

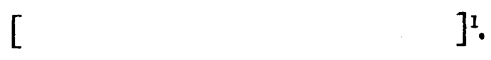

[§1.] (43) In licteris uestris et reuerentia debita et affectione receptis quam repatriatio mea cure sit uobis $e^{2}$ animo grata mente ac diligenti animauersione $\mathrm{e}^{3}$ (44) concepi/et inde tanto me districtius obligastis $^{5}$ quanto rarius exules inuenire amicos contingit. Ad illarum ${ }^{6}$ vero singnificata ${ }^{7}$ responsio et si non erat qualem ${ }^{8}$ forsan (45) pusillanimitas appeteret aliquorum ut sub examine uestri consilij ${ }^{9}$ ante iudicium uentiletur ${ }^{10}$ affectuose deposco.

[\$2.] Ecce igitur quod per licteras uestri meique nepotis (46) nec non aliorum quam plurium ${ }^{11}$ amicorum singnificatum est miki per ordinamentum nuper factum ${ }^{12}$ Florentie $^{13}$ super absolutione bannitorum quod si soluere uellem certam (47) pecunie quantitatem uellemque pati notam oblationis ${ }^{14}$ et absolui' possem ${ }^{15}$ et redire ad ${ }^{16}$ presens In qua ${ }^{17}$ quidem duo ridenda et male preconsiliata ${ }^{18}$ sunt (48) pater dico male preconsiliata ${ }^{18}$ per illos qui talia ${ }^{19}$ expresserunt nam uestre lictere discretius et consultius clasulate. nicil de talibus continebant.

[§3.] Est ne ista (49) reuocatio gratiosa ${ }^{20}$ qua dantes allagherii ${ }^{21}$ reuocatur ad patriam per trilustrium fere perpessus ${ }^{22}$ exilium. hoc $\mathrm{ne}^{23}$ meruit innocentia ${ }^{24}$ manifesta quibuslibet. hoc ${ }^{25}$ sudor et labor (50) continuatus in studio ${ }^{26}$ absit a uiro philosophie domestico temeraria tantum ${ }^{27}$

1 There is no title to the letter in MS.; D1.D2 . Epistola di Dante; F $. T . F^{2} . G . O . P$. Amico Florentino.

2 So M.; D $\mathrm{D}^{1}$.-P. ex.

3 So $\mathrm{D}^{1}$.C.R.Fo.; D².Pe.W.F1.T.M.F².G.O.P. animadversione.

4 So M.F'.G.O.P. ; D D. $^{2}$.C.R.Fo.Pe.W.F1.T. etenim.

5 So $\mathrm{D}^{1}$.-P.; $\mathrm{D}^{2}$. obligatis.

6 So $D^{1} . D^{2} . P e . W . F^{1} . T . M . F^{2}$.G.O.P.; C.Fo. illam; R. illorum.

7 So $\mathrm{D}^{1}$.- $\mathrm{P}$., though $\mathrm{D}^{1}$ erroneously gives singula as the MS. reading.

8 So M.; $\mathrm{D}^{1} . \mathrm{D}^{2}$.C.R.Fo.Pe.W.F'.T. respondeo, et si non eatenus qualiter; $\mathrm{F}^{2}$.G.O.P. respondeo; et si responsio non erit qualiter; $\mathrm{D}^{1}$. erroneously gives the MS. reading as erit instead of erat; To. holds erat to be untenable, and proposes to read erit.

9 C. concilii.

10 So $\mathrm{D}^{1} . \mathrm{D}^{2}$.C.R.Pe.W.F'.T.M.F ${ }^{2}$.O.; Fo. consilii sit ante judicium; G. consilii antea judicium ventiletur; P. consilii judicium ventiletur.
11 Fo. quamplurimum.
${ }_{12} \mathrm{D}^{2}$. ordinationem nuper factam.

13 P. Florentian (!)

14 M. oblatoris.

15 W.F'.T. posse; D $\mathrm{D}^{1}$-P. possem. $\quad{ }^{16}$ Fo. at. $\quad{ }^{17}$ So P.; D $\mathrm{D}^{1}$ - O. quo.

18 C.Fo. perconsiliata; D $\mathrm{D}^{1}$ - - P. praeconsiliata. $\quad 19 \mathrm{D}^{1}$.C. tali; $\mathrm{D}^{2}$.-P. talia.

20 D1.D2.C.R.Fo.Pe.W.F'.T.F'G.O. gloriosa; M.To.P. generosa.

21 D.D2.C.Pe. d. alla.; R.T.M. D. Alla.; Fo. d. all.; W.F ${ }^{1}$. Dantes Alligherius; $\mathrm{F}^{2}$. Dantes Alagherii; G. Dantes Allagherius; 0 . Dantes Aligherius; P. Dantes Alighierius (!).

22 Pe. perpessum.

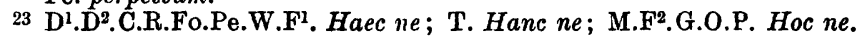

24 C.Fo. conscientia; D - - P. innocentia.

$25 \mathrm{D}^{1} . \mathrm{D}^{2}$.C.R.Fo.Pe.W.Fi.T. Haec; M.F' ${ }^{2}$ G.O.P. Hoc.

${ }_{26}$ C.Fo. studits; $\mathrm{D}^{1}$.-P. studio. ${ }_{27}$ So M.P.; $\mathrm{D}^{1}$.-O. terreni. 
cordis humilitas ut more cuiusdam cioli ${ }^{1}$ et aliorum infamium ${ }^{2}$. quasi uictus $^{3}$ ipse se (51) patiatur offerrit. absit a uiro predicante iustitiam ut perpessus iniurias / iniuriam inferentibus ${ }^{5}$ uelud bene merentibus pecuniam suam soluat ${ }^{6}$.

[\$4.] Non est hec (52) uia redeundi ad patriam pater mi Sed $\mathrm{si}^{7}$ alia per uos autem ${ }^{8}$, deinde per alios inuenitur ${ }^{9}$, que fame dantis que honori ${ }^{10}$ non deroget illam non lentis passibus acceptabo (53) Quod si per nullam talem florentia introitur" numquam Florentiam introibo Quidni? non ${ }^{12}$ solis astrorumque specula ubique conspiciam nonne dulcissimas ueritates potero (54) speculari ubique sub celo. Ni prius inglorium ymo ingnominiosum. populo Florentino ciuitati ${ }^{13}$ me reddam quippe nec panis deficiet.

\section{Proposed emendations in the Oxford text of Epist. IX.}

Title. For Amico Florentino read [Amico Florentino] to indicate that the title is an editorial interpolation.

1. 3. For ex animo read (with MS., Muzzi, and Della Torre) et animo.

11. 8-9. For significata respondeo; et si responsio non erit qualiter read (with MS., Muzzi, and Della Torre ${ }^{14}$ ) s. responsio etsi non erit (MS., Muzzi erat) qualem.

1. 21. For In quo read (with $M S$.) In qua ${ }^{15}$.

1. 27. For revocatio gloriosa read (with $M S$.) revocatio gratiosa ${ }^{16}$.

1. 28. For Dantes Aligherius read Dantes Alagherii ${ }^{17}$.

1 W.F1.T. scioli; D1.-P. Cioli.

2 C. infamiam; Fo. infamia; $D^{1}$.-P. infanium; $D^{1}$. gives infirmium as the MS. reading, which is doubtful.

3 So $D^{2}$.M.F'-O.P.; D $D^{1}$.C.R.Fo.Pe.W.F'.T.G. vinctus.

5 So $\mathrm{D}^{2}$.M.F'.G.O.P.; D'.C.R.Fo.Pe.W.F'.T. perpessus injuriam, inferentibus.

$6 \mathrm{M}$. bene merentibus pecunias, suam solvat. ${ }_{7} \mathrm{Pe}$. omits si.

8 So MS. ; D D.C.R.Fo.Pe.W.F $^{1}$ T.M.F 2 G.O. aut; $\mathrm{D}^{2}$. (probably by a misprint) ut; To.P. ante.

9 So M.; $\mathrm{D}^{1}$.-P. invenietur.

10 So Di.D". C.R.Fo.Pe.M.P.; W.T. quae famae Dantis, quae honori; F'. $\mathrm{F}^{2}$.G.O. quae famae Dantis atque honori.

11 M. Florentiae introitur; T. Florentiâ i.; G.Florentiami.; D1.D2 .C.R.Fo.Pe.W.F'.F².O.P. Florentia $i . ; \mathrm{D}^{1}$ erroneously gives foret introitus as the MS. reading.

12 So MS. M. ; $D^{1}$.-P. To. Nonne.

13 So M.P.; $\mathrm{D}^{1} .-0$. populo Florentinaeque civitati; $\mathrm{D}^{1}$. erroneously gives properè Florentiae civitati as the MS. reading.

14 See Bull. Soc. Dant. Ital., N.S. XII, p. 123, nn. c, d.

15 The antecedent being, as Della Torre observes (loc. cit.), 'absolutione bannitorum' of 1.17.

16 The MS. reading grosa can only stand for gratiosa; not for gloriosa (with Dionisi, etc.), which would be glosa in MS.; nor for generosa (with Muzzi and Della Torre), which would be gnosa. (See my note on $A$ misreading in Dante's Letter to a Friend in Florence, in Bull. Soc. Dant. Ital., N.S. xx, pp. 58-9.)

17 This, as I have pointed out in a previous article (see Mod. Lang. Rev., vir, p. 12, n. 7), is the recognized Latinized form of Dante's name. 


\section{The Laurentian Text of Dante's Letter to a Friend}

1. 33. For temeraria terreni cordis humilitas read (with Muzzi, and Della Torre) temeraria tantum ${ }^{1}$ cordis humilitas.

1. 35. For quasi victus read (with the early editors) quasi vinctus?.

11. 41-2. For per vos aut deinde per alios read per vos antecedenter", deinde per alios.

1. 42. For invenietur read (with MS. and Muzzi) invenitur.

11. 42-3. For famae Dantis atque honori read (with MS. and the early editors) famae Dantisque honori.

11. 50-2. For ignominiosum, populo Florentinaeque civitati me reddam read (with MS. and Muzzi) ignominiosum populo Florentino 4 , civitati me reddam.

\section{Text of Epist. IX as emended 5 .}

\section{[Amico Florentino.]}

[§ 1.] In literis vestris, et reverentia (2) debita et affectione receptis, quam re-(3)-patriatio mea curae sit vobis et animo, (4) grata mente ac

1 The MS. reading is in a sense indeterminate, as it may be meant for either $t m$, or tni, or tin. The last is out of the question here. The second, in order to represent terreni (the reading of Dionisi, etc.), should have a loop after the $t$, which, however, might have been accidentally omitted by the scribe. The $t m$ of the MS. normally represents tantum, which word seems to be required by the construction as the correlative of the ut of 1.34 .

2 The MS. reading is victus, which, by the accidental omission of the stroke over the $i$ (representing $n$ ), may not improbably be a copyist's error for vinctus, the reading adopted by the majority of editors. The sense of vinctus ('like a prisoner in bonds') is much more appropriate to the context than that of victus (which would imply rather a prisoner of war), the point being that the person who was presented at the oblatio, as a preliminary to being pardoned, was either actually or technically a prisoner; if an actual malefactor, he was brought from the prison where he had been confined; if a political offender, he was obliged to cross the threshold of the prison, so as to constitute himself technically a prisoner. (On the oblatio, see Zenatti, Daute e Firenze, pp. $507 \mathrm{ff}$; and Bull. Soc. Dant. Ital., N.S. xI, p. 29 ; xIr, p. 155.)

3 The MS. reading is aut, with a stroke over it, which is the normal abbreviation of autem; but as autem cannot possibly be the correct reading, the early editors one and all substituted aut. As $u$ and $n$ are almost indistinguishable in MSS., Della Torre proposes to read ante, which is adopted in his text by Passerini ; but the recognized abbreviation of ante is $a \bar{n}$ (with a stroke over the $n$ ), and it is so written in this MS. where the word occurs at the beginning of the letter (1. 11, 'ante judiciunn'). On the other hand, it has been pointed out by liostagno that ant with a loop over the $t$ is the regular abbreviation of antecedenter. As this word suits the sense, and its adoption involves only a very slight departure from the MS. reading, antecedenter seems preferable to ante. One or other of these would appear to be required as the correlative to the following deinde. (See Bull. Soc. Dant. Ital. xiI, p. 125, n.)

4 The MS. reads simply Flor. without any trace of que, the insertion of which was due to Dionisi in the first instance. The restoration of the MS. reading necessitates an alteration in the usual English rendering of this passage. Foscolo and other English trinslators render: ' unless I first render myself inglorious, nay ignominious, in the eyes of the people and city of Florence.' The sense of the passage as emended would be: ' unless I first return to my wative city, disgraced, nay dishonoured, in the eyes of the people of Florence.'

5 For convenience of reference the numbering of the sections [in square brackets], and of the lines (in round brackets), of the text as printed in the Oxford Daute have been inserted in the emended text. 
diligenti animadversione (5) concepi; et inde tanto me districtius (6) obligastis, quanto rarius exules invenire (7) amicos contingit. Ad illarum vero sig-(8)-nificata responsio, etsi non (9) erit qualem forsan pusillanimitas appe-(10)-teret aliquorum, ut sub examine vestri (11) consilii ante iudicium ventiletur, affec-(12)-tuose deposco.

[§ 2.] (13) Ecce igitur quod per litteras vestri (14) meique nepotis, nec non aliorum quam-(15)-plurium amicorum, significatum est mihi (16) per ordinamentum nuper factum Floren-(17)-tiae super absolutione bannitorum: quod (18) si solvere vellem certam pecuniae quanti(19)-tatem, vellemque pati notam oblationis, (20) et absolvi possem et redire ad praesens. (21) In qua quidem duo ridenda et male prae(22)-consiliata sunt, Pater; dico male prae-(23)-consiliata per illos qui talia expresserunt, (24) nam vestrae litterae discretius et con-(25)-sultius clausulatae nihil de talibus con-(26)-tinebant.

[§ 3.] (27) Estne ista revocatio gratiosa, qua (28) Dantes Alagherii revocatur ad patriam, (29) per trilustrium fere perpessus exilium? (30) Hocne meruit innocentia manifesta qui-(31)-buslibet? Hoc sudor et labor continuatus (32) in studio? Absit a viro philosophiae (33) domestico temeraria tantum cordis hu-(34)-militas, ut more cuiusdam Cioli et ali-(35)-orum infamium, quasi vinctus ipse se (36) patiatur offerri! Absit a viro praedicante (37) iustitiam ut perpessus iniurias, iniuriam (38) inferentibus, velut benemerentibus, pe-(39)-cuniam suam solvat!

[§ 4.] (40) Non est haec via redeundi ad patriam, (41) Pater mi; sed si alia per vos antecedenter, deinde (42) per alios invenitur, quae famae Dantis-(43)-que honori non deroget, illam non (44) lentis passibus acceptabo. Quod si per (45) nullam talem Florentia introitur, num(46)-quam Florentiam introibo. Quidni ? (47) nonne solis astrorumque specula ubique (48) conspiciam? Nonne dulcissimas verita-(49)-tes potero speculari ubique sub coelo, ni (50) prius inglorium, immo ignominiosum, (51) populo Florentino, civitati me red-(52)-dam? Quippe nec panis deficiet.

\section{Translation.}

\section{[To a Friend in Florence.]}

[§ 1.] From your letter, which I received with due respect and affection, and have diligently studied, I learn with gratitude how my recall to Florence has been the object of your care and concern; and I am the more beholden to you therefor, inasmuch as it rarely happens 


\section{The Laurentian Text of Dante's Letter to a Friend}

that an exile finds friends. My reply to what you have written, although perchance it be not of such tenour as certain faint hearts would desire, I earnestly beg may be carefully examined and considered by you before judgment be passed upon it.

[§2.] I gather, then, from the letter of your nephew and mine ${ }^{1}$, as well as from those of sundry other friends, that, by the terms of a decree lately promulgated in Florence touching the pardon of the exiles, I may receive pardon, and be permitted to return forthwith, on condition that I pay a certain sum of money, and submit to the stigma of the oblation ${ }^{2}$ - two propositions, my Father, which in sooth are as ridiculous as they are ill-advised, ill-advised, that is to say, on the part of those who have communicated them, for in your letter, which was more discreetly and cautiously formulated, no hint of such conditions was conveyed.

[§3.] This, then, is the gracious recall of Dante Alighieri to his native city, after the miseries of well-nigh fifteen years of exile! This is the reward of innocence manifest to all the world, and of the sweat and toil of unremitting study! Far be it from a familiar of philosophy to commit such a senseless act of abasement as voluntarily to present himself, like a felon in bonds, at the oblation, as one Ciolo and other infamous wretches have done! Far be it from the preacher of justice, after suffering wrong, to pay of his money to those that wronged him, as though they had deserved well of him!

[§ 4.] No! my Father, not by this path will I return to my native city. If some other can be found, in the first place by yourself and then by others, which does not derogate from the fame and honour of Dante, that will I tread with no lagging steps. But if by no such path Florence may be entered, then will I enter Florence never. What! can I not anywhere gaze upon the face of the sun and the stars? can I not under any sky contemplate the most precious truths, without I first return to Florence, disgraced, nay dishonoured, in the eyes of my fellowcitizens? Assuredly bread will not fail me!

Fiveways, Burnham, Bucks.

Paget Toynbee.

1 There is reason to suppose that this common nephew of Dante and of his correspondent was one Niccolò Donati, son of Foresino (or Forese) di Manetto Donati, the brother of Dante's wife, Gemma Donati. In this case Dante's correspondent, whom he addresses as 'Pater' (1l. 22, 41), would be another brother of Gemma's, Teruccio di Manetto Donati, who was a member of a religious order, and a bachelor of divinity. (See Bull. Soc. Dant. Ital., N.S. xII, p. 160.)

2 See p. 66, n. 2. 